\title{
NILAI-NILAI PERSONALITAS ENTREPRENEURSHIP DAN PRODUKTIVITAS USAHA MIKRO RUMPUT LAUT
}

\author{
Hasmiah Herawaty \\ IAIN Parepare \\ hasmiahherawati@iainpare.ac.id
}

\begin{abstract}
ABSTRAK
Penelitian ini mengidentifikasi nilai-nilai personalitas entrepreneurship yang terdiri dari sikap disiplin, jujur, kreativitas, inovasi dan mandiri dan menguji pengaruhnya terhadap terhadap produktivitas pelaku usaha rumput laut skala mikro. Penelitian ini dilakukan di desa Lasitae, desa Pancana dan kelurahan Tanete dengan 66 responden. Data dianalisis menggunakan regresi berganda. Hasil penelitian menunjukkan bahwa nilai kepribadian yang terdiri dari disiplin, jujur, kreativitas, inovasi dan mandiri berpengaruh terhadap produktivitas pelaku usaha rumput laut.
\end{abstract}

Kata kunci: disiplin, jujur, kreativitas, inovasi, mandiri, produktivitas

\begin{abstract}
This research identifies the personality values of entrepreneurship consisting of dicipline, honesty, creativity, innovation, and independence and test those effect on the productivity of seaweed entrepreneur of micro scale. This research was conducted in Lasitae Village, Pancana Village of Tanete Sub-district with 66 respondents. The data were analyzed using multiple regression. The result of this research pointed out personality values consisting of discipline, honesty, creativity, innovation, and independence affect the productivity of seaweed entrepreneur.
\end{abstract}

Keywords: discipline, honesty, creativity, innovation, independence, productivity

\section{PENDAHULUAN}

Nilai kepribadian kewirausahaan merupakan nilai- nilai yang melekat pada diri seseorang dan akan mempengaruhi perilaku pada seluruh situasi. Penanaman nilai kepribadian kewirausahaan dapat memberikan efek terhadap pengembangan usaha. Suryana (2008) menyatakan bahwa nilai kepribadian kewirausahaan adalah sifat, jiwa dan semangat yang didasarkan pada motivasi berprestasi (need of achievment), kejujuran (honestly), ketaatan, kedisiplinan (disciple), percaya diri (self confidence). Dengan sifat, jiwa dan semangat kewirausahaan ini, sedikit saja ada peluang dan kesempatan, dia mampu mengubah, menghasilkan sesuatu yang baru, relasi baru, akumulasi modal, baik berupa perbaikan usaha yang sudah ada (upgrading) maupun menghasilkan usaha baru. Penerapan nilai kepribadian kewirausahaan akan menimbulkan keyakinan yang tercermin dalam sikap dan kepribadian seseorang dalam memandang sesuatu. Nilai kepribadian kewirausahaan merupakan bagian dari faktor penunjang ketersediaan pelaku-pelaku usaha yang mandiri dan memiliki kepribadian yang unggul. Kepribadian unggul artinya nilai watak usaha yang sangat tinggi dimana hal tersebut harus dimiliki oleh setiap wirausaha sebagai pelaku usaha baik mikro, kecil, menengah, besar, serta koperasi. Sehingga dianggap perlu bagi setiap individu untuk memperoleh pendidikan tentang Entreprenuership.

Penerapan nilai kepribadian oleh wirausaha juga berpengaruh terhadap peningkatan produktivitas. Armstrong (2003) mengemukakan bahwa seorang wirausahawan mampu menggeser sumber daya ekonomi dari bidang produktivitas yang lebih rendah ke bidang yang lebih tinggi dan hasil yang lebih besar. Salah satu faktor utama dalam pertumbuhan sebuah sistem ekonomi adalah produktivitas, yaitu ukuran pertumbuhan ekonomi yang membandingkan berapa banyak yang diproduksi oleh sebuah sistem dengan berapa banyak sumber daya yang dibutuhkan untuk memproduksinya. Sehingga peningkatan produktivitas 
tentunya memerlukan pengetahuan Entreprenuership sebagai salah satu faktor penunjang utama.

Penerapan pengetahuan Entreprenuership dalam pembentukan karakter wirausaha melalui penerapan nilai kepribadian kewirausahaan sangatlah penting. Hal ini bertujuan untuk membangun mental masyarakat khususnya generasi muda agar tidak sekedar menjadi pencari kerja, tapi pencipta lapangan kerja.

Dalam rangka lebih meningkatkan jumlah Entreprenuer yang mempunyai kepribadian unggul yang mengarah pada peningkatan produktivitas, pemahaman tentang nilai kepribadian kewirausahaan perlu ditindak lanjuti dengan penerapan yang di implimentasikan dalam semua aspek kegiatan usaha termasuk didalamnya bidang perikanan dan kelautan.

Kabupaten Barru sebagai salah satu daerah di Provinsi Sulawesi Selatan yang terletak pada posisi lintas dengan bentangan pantai $78 \mathrm{~km}$, dengan garis pantai yang memanjang merupakan daerah potensi pengembangan sumber daya kelautan dan perikanan termasuk pembudidayaan komoditas rumput laut. Sejak diundangkannya pengembangan potensi kekayaan sumber daya alam lokal milik daerah diantaranya potensi perikanan dan kelautan yang diatur dalam Undang-undang Nomer 32 Tahun 2004 (OTODA) Pasal 18 ayat (1) "Daerah yang memiliki kekayaan laut diberi kewenangan mengelola sumber daya di wilayah laut" dan ayat (2) "Daerah mendapatkan bagi hasil atas pengelolan sumber daya alam dibawah dasar dan/atau didasar laut sesuai dengan ketentuan perundang-undangan", dengan memberdayakan potensi masyarakat sebagai mitra pemerintah merupakan salah satu dari implementasi pelaksanaan otonomi daerah tersebut.

Pengelolaan potensi perikanan dan kelautan khususnya budidaya rumput laut di Kabupaten Barru tentunya memerlukan peran serta pelaku usaha rumput laut (pelaku UMKM) sebagai pelaku utama dalam pengembangan komoditas rumput laut. Pengembangan UMKM dewasa ini sudah mulai mendapatkan perhatian yang serius dari pemerintah pusat dan daerah. Terbukti dengan adanya perlindungan hukum dari pemerintah Undang-Undang Usaha Mikro Kecil dan Menengah no 20 tahun 2008 pasal 1. Semua upaya itu dilakukan untuk memberdayakan perekonomian rakyat dalam rangka peningkatan kesejahteraan secara keseluruhan.

. Upaya yang telah dilakukan oleh Dinas Kelautan dan Perikanan guna pengembangan potensi kelautan termasuk budidaya komoditas rumput laut (Eucheuma cottonii), diantaranya memberikan bantuan modal serta program penyuluhan dan pelatihan untuk meningkatkan pengetahuan dan keterampilan pelaku usaha rumput laut yang mengarah pada peningkatan produktivitas. Namun fenomena yang ditemukan dilapangan melalui hasil wawancara dengan Tenaga Teknis dan Pengolah Data Statistik Budidaya Dinas Kelautan dan Perikanan Kabupaten Barru mengemukakan bahwa sejumlah pelaku usaha rumput laut belum semua menjalankan materi pelatihan yang telah diberikan. Hal ini mengindikasikan bahwa pada umumnya pelaku usaha rumput laut belum memiliki nilai kepribadian kewirausahaan.

Disamping itu dapat diindikasikan pula bahwa kegiatan pelatihan dan penyuluhan lebih menekankan pada aspek materi pelatihan bukan pada penanaman nilai kepribadian kewirausahaan yang dapat memberikan kontribusi terhadap peningkatan produktivitas pelaku usaha sehingga berdampak pada jumlah kapasitas produksi, nilai produksi dan luas area pembudidayaan rumput laut. Pemanfaatan luas area lahan yang dipergunakan untuk budidaya rumput laut hingga tahun 2012 baru berkisar 200 Ha yang digarap oleh 200 RTP (Rumah Tangga Perikanan) sedangkan potensi area lahan budidaya rumput laut menurut data Dinas Kelautan dan Perikanan adalah $1200 \mathrm{Ha}$. Hal ini mengindikasikan bahwa sejumlah pelaku usaha rumput laut belum sepenuhnya memiliki kesadaran untuk lebih memanfaatkan potensial lahan yang tersedia serta belum mempunyai keinginan untuk mengelola dan mengembangkan usaha budidaya rumput laut dengan teknik pengolahan yang lebih baik. Sehingga dapat dikemukakan bahwa belum semua pelaku usaha rumput laut skala mikro memiliki nilai kepribadian kewirausahaan yang berorientasi pada peningkatan produktivitas.

Melihat kenyataan tersebut menunjukkan bahwa sebahagian besar usaha mikro tumbuh secara alamiah yang merupakan usaha keluarga secara turun temurun. Keterbatasan SDM usaha kecil baik dari segi pendidikan formal, maupun pengetahuan dan keterampilannya 
sangat berpengaruh terhadap manajemen pengelolaan usaha, sehingga usaha tersebut sulit berkembang. Implementasi dari UU.No 20 tahun 2008 adalah pemberian pengetahuan Entreprenuership diantaranya melalui pemahaman dan penerapan nilai kepribadian kewirausahaan kepada pelaku usaha mikro dalam hal ini petani rumput laut, sehingga diharapkan mampu menjawab tantangan perbaikan kualitas SDM yang ada. Implementasi dari penerapan nilai kepribadian kewirausahaan akan menjadi salah satu barometer peningkatan produktivitas dari petani rumput laut yang ada di Kabupaten Barru, Provinsi Sulawesi Selatan.

Penelitian ini bertujuan untuk megetahui pengaruh nilai personalitas atau kepribadian kewirausahaan terhadap peningkatan produktivitas pelaku usaha rumput laut skala mikro, nilai disiplin, jujur, kreativitas ,inovasi, dan mandiri divariabelkan dalam penelitian ini.

\section{TINJAUAN PUSTAKA}

Nilai kepribadian kewirausahaan adalah sesuatu yang fundamental dalam aktivitas setiap insan. Adapun nilai kepribadian yang dimaksud adalah nilai yang melekat pada seorang pemilik yang sekaligus juga pemimpin dalam usaha. Suryana (2008) mengemukakan bahwa: yang dapat disebut wirausahawan bukan hanya mereka yang mempunyai perusahaan, toko, pabrik dan sebagainya, tetapi mereka yang mempunyai ciri-ciri pribadi dan karakteristik wirausaha juga dapat dikatakan sebagai wirausahawan, apapun profesi dan pekerjaannya.

Penanaman nilai-nilai kepribadian kewirausahaan akan tercermin dalam sikap dan prilaku wirausaha yang menjadi karakteristik wirausaha itu sendiri. Karakteristik wirausaha menjadi potensi diri yang mempengaruhi sifat kepribadian seorang wirausaha dan akan membawa pengaruh positif terhadap aktivitas dalam segala situasi. Sebaliknya, seseorang yang tidak memiliki nilai kepribadian wirausaha akan membawa dampak pengaruh negatif terhadap aktivitas usaha. Seorang wirausaha yang menerapkan karakteristik wirausaha akan mampu mempengaruhi dan merubah tata cara mengelola usaha yang mengarah pada prestasi usaha dibandingkan dengan wirausaha yang tidak menerapkan karakteristik wirausaha. Adapun nilai kepribadian kewirausahaan yang dimaksud dalam penelitian ini adalah disiplin, jujur,kreativitas, inovasi dan mandiri.

\section{Disiplin}

Disiplin adalah sikap menaati ketentuan dan aturan yang telah ditetapkan tanpa pamrih, tanpa menghiraukan suasana emosional dan tanpa pengawasan eksternal. Pengertian disiplin menurut Nasution (1972), disiplin adalah usaha untuk mengatur atau mengontrol kelakuan seseorang untuk mencapai tujuan, dengan adanya bentuk kelakuan yang harus dicapai, dilarang atau diharuskan. Selanjutnya Pridjodarminto (1994) menyatakan bahwa disiplin adalah suatu kondisi yang tercipta dan terbentuk melalui proses dari serangkaian perilaku yang menunjukkan nilai-nilai ketaatan, kepatuhan, kesetiaan, keteraturan, dan atau ketertiban. Disiplin yang baik tidak tercapai bila kelakuan seseorang terlampau dikendalikan oleh macam-macam peraturan dan tindakan, tetapi mestinya disiplin tumbuh sendiri dalam diri seseorang yang merasa terpanggil (self-dicipline). Sikap dan prilaku disiplin pada hakekatnya merupakan penentu "nilai" dan "harga" diri seseorang. Seseorang yang mempunyai disiplin tinggi akan mempunyai integritas diri, kepedulian baik terhadap pekerjaan, rekan kerja, tim kerja maupun terhadap organisasi. Sikap disiplin diri mampu membawa seseorang hidup secara lebih teratur dalam lingkungan manapun.

\section{Jujur}

Jujur merupakan sifat yang tertanam dalam diri manusia antara menyampaikan dengan kenyataan adalah sama tanpa ada penambahan atau pengurangan sepatah katapun. Jujur dalam berwirausaha artinya mau dan mampu mengatakan sesuatu sebagaimana adanya. Setiap hasil yang dicapai oleh wirausaha merupakan hasil dari perjuangan dan pengorbanan. Disinilah makna kejujuran harus dipandang sebagai guru dan anugrah untuk mendorong rasa optimis guna mendapatkan kemajuan dalam berusaha. Penerapan dari sikap jujur dan selalu ingin maju akan membawa dampak sebagai berikut : (1) Dipercaya oleh 
masyarakat konsumen, (2) Memiliki rasa percaya yang kuat, (3) Memiliki mental yang kuat, (4) Memiliki kesabaran, (5) Selalu tabah

\section{Kreativitas}

Secara umum kreativitas diartikan kemampuan untuk membuat kombinasi baru atau produk baru atau kemampuan seseorang dalam melahirkan sesuatu yang baru baik berupa gagasan, maupun karya nyata yang relatif berbeda dengan apa yang telah ada sebelumnya (Mardiatmo, 2006). Kreativitas bukanlah suatu bakat misterius yang diperuntukkan hanya bagi segelintir orang. Mengingat kreativitas merupakan suatu cara pandang yang sering kali justru dilakukan secara tidak logis. Proses ini melibatkan hubungan antar banyak hal di mana orang lain kadang-kadang tidak atau belum memikirkannya. Yang dimaksud kreativitas dalam hal ini adalah menghadirkan suatu gagasan baru.

\section{Inovasi}

Inovasi adalah suatu penemuan baru yang berbeda dari produk sebelumnya. Inovasi dapat juga diartikan sebagai proses menemukan atau mengimplementasikan sesuatu yang baru ke dalam situasi yang baru. Konsep kebaruan ini berbeda bagi kebanyakan orang karena sifatnya relative. Maksudnya adalah apa yang dianggap baru merupakan lama bagi orang lain dalam konteks lain. Inovasi merupakan memikirkan dan melakukan sesuatu yang baru untuk menambahkan nilai manfaat dari suatu barang atau produk.

Inovasi dapat menjadi positif atau negatif. Inovasi positif didefenisikan sebagai proses membuat perubahan terhadap sesuatu yang telah mapan dengan memperkenalkan sesuatu yang baru memberikan nilai tambah bagi pengguna. Sedangkan inovasi negatif menyebabkan orang enggan memakainya karena tidak memiliki nilai tambah, merusak dan merugikan (Jong, 2003)

\section{Mandiri}

Mandiri adalah sikap tidak bergantung kepada pihak lain dalam mengambil tindakan, mengambil keputusan, serta dalam memilih berbagai aktivitas untuk mencapai tujuan. Sumahamijaya (2001) kemandirian sebagai adanya hak dan kewajiban yang dimiliki, mampu menentukan nasibnya sendiri, tidak tergantung pada orang lain sampai batas kemampuan, mampu bertanggung jawab atas segala tindakan dan perasaan, mampu membuang pola perilaku yang mengingkari diri sendiri.

Orang yang mandiri adalah orang yang berani mengambil keputusan dan bertindak sendiri tanpa harus bergantung pada orang lain. Sikap mandiri ini tumbuh dari adanya rasa percaya pada orang lain. Hal ini bukan berarti yang mandiri tidak memerlukan orang lain dalam hidupnya. Sebagai makhluk sosial tentunya setiap manusia pasti membutuhkan orang lain. Hanya bagi orang mandiri kebutuhan terhadap orang lain tidak meningkat menjadi ketergantungan terhadap orang lain.

\section{METODE PENELITIAN}

Penelitian ini dilakukan di desa Lasitae, desa Pancana dan kelurahan Tanete dengan menggunakan 66 responden sebagai sampel. menggunakan pendekatan deskriptif kuantitatif dimana untuk menganalisis produktivitas menggunakan regresi berganda. Teknik pengambilan sampel menggunakan proportionate stratified random sampling, sedangkan pengumpulan data menggunakan tehnik angket (kuesioner), observasi dan wawancara. Metode yang digunakan adalah skala Likert. Atribut yang dipertimbangkan adalah Nilai Kepribadian Kewirausahaan: disiplin, jujur, kreativitas, inovasi dan mandiri.

\section{Variabel dan Definisi Operasional}

Variabel penelitian adalah variabel independen dan dependen. Variabel dependen dalam penelitian ini adalah produktivitas, sedangkan variabel independen adalah nilai personalitas kewirausahaan yang didimensikan oleh nilai disiplin, jujur, kreativitas, dan inovasi. Produktivitas yaitu ukuran pertumbuhan ekonomi yang membandingkan berapa banyak yang diproduksi oleh sebuah sistem dengan berapa banyak sumber daya yang 
dibutuhkan untuk memproduksinya. Nasution (1972) mendefinisikan disiplin sebagai usaha untuk mengatur atau mengontrol kelakuan seseorang untuk mencapai tujuan, dengan adanya bentuk kelakuan yang harus dicapai, dilarang atau diharuskan. Pada variabel jujur, itu didefinisikan sebagai sifat yang tertanam dalam diri manusia antara menyampaikan dengan kenyataan adalah sama tanpa ada penambahan atau pengurangan sepatah katapun. Jujur dalam berwirausaha artinya mau dan mampu mengatakan sesuatu sebagaimana adanya.. Secara umum kreativitas diartikan kemampuan untuk membuat kombinasi baru atau produk baru atau kemampuan seseorang dalam melahirkan sesuatu yang baru baik berupa gagasan, maupun karya nyata yang relatif berbeda dengan apa yang telah ada sebelumnya (Mardiatmo, 2006). Variabel independen selanjutnya adalah inovasi dan mandiri. Inovasi diartikan sebagai proses menemukan atau mengimplementasikan sesuatu yang baru ke dalam situasi yang baru. Kemandirian sebagai adanya hak dan kewajiban yang dimiliki, mampu menentukan nasibnya sendiri, tidak tergantung pada orang lain sampai batas kemampuan, mampu bertanggung jawab atas segala tindakan dan perasaan, mampu membuang pola perilaku yang mengingkari diri sendiri (Sumahamijaya, 2001).

\section{Teknik Analisis Data}

Data dianalisis menggunakan metode analisis regresi linier berganda. Adapun persamaan regresinya sebagai berikut.

Dimana,

$$
Y=\alpha+\beta X 1+\beta 2 X 2+\beta 3 X 3+\beta 4 X 4+\beta 5 X 5 \varepsilon
$$

$$
\begin{aligned}
& Y=\text { Produktivitas } \\
& X 1=\text { Disiplin } \\
& \text { X2 = Jujur } \\
& \text { X3 = Kreativitas } \\
& \text { X4 = Inovatif } \\
& \text { X5 = Mandiri }
\end{aligned}
$$

\section{HASIL DAN PEMBAHASAN}

Disiplin, jujur, kreaivitas, inovatif, dan mandiri diuji pengaruhnya terhadap produktivitas sebagai variabel dependen. Untuk menjawab rumusan masalah dalam penelitian ini, maka dilakukan pengujian secara simultan (serentak) dan secara parsial (sendiri-sendiri) antara variabel independen terhadap variabel dependen.

\section{Pengujian Secara Simultan (F-tes)}

Uji F dilakukan untuk menguji apakah secara simultan variabel Disiplin, Jujur Kreativitas, Inovatif dan Mandiri berpengaruh signifikan terhadap Produktivitas Pelaku Usaha Rumput Laut Skala Mikro. Apabila nilai F-hitung lebih besar dari nilai F-tabel dan nilai

\begin{tabular}{|c|c|c|c|c|c|c|}
\hline Model & $\begin{array}{l}\text { Sum of } \\
\text { Squares }\end{array}$ & Df & $\begin{array}{l}\text { Mean } \\
\text { Square }\end{array}$ & F-hitung & F-tabel & Sig. \\
\hline Regression & 751.544 & 5 & 150.309 & 20.729 & 2.37 & $.000^{a}$ \\
\hline Residual & 435.077 & 60 & 7.251 & & & \\
\hline Total & 1186.621 & 65 & & & & \\
\hline
\end{tabular}
Probabilitas lebih kecil dari a yang sudah ditentukan sebesar $(0,05)$, maka model yang diuji adalah signifikan. Sebaliknya apabila nilai F-hitung lebih kecil dari nilai F-tabel dan nilai Probabilitas lebih besar dari $\alpha$ yang sudah ditentukan sebesar $(0,05)$, maka model yang diuji adalah tidak signifikan. Hasil ringkasan (summary) uji kebersamaan variabel bebas terhadap variabel terikat dapat dilihat:

Tabel 1. Hasil Uji F ANOVA

Sumber : Data Primer Diolah 
Berdasarkan tabel 1, diperoleh F-hitung sebesar 160,369 dibandingkan dengan nilai F-tabel pada taraf signifikan $\alpha=0,05$ dengan $d k=n-5.1$ Nilai F-tabel sebesar 2,37 (lihat lampiran E). Nilai F-hitung sebesar 20,729 lebih besar dari nilai F-tabel $(2,37)$ dengan nilai probabilitas sebesar 0,000 dimana nilainya lebih kecil dari taraf signifikan $\alpha=0,05$ maka ini menunjukkan bahwa secara simultan variabel Disiplin, Jujur dan Kreativitas, Inovatif dan Mandiri berpenaruh signifikan terhadap Produktivitas Pelaku Usaha Rumput Laut Skala Mikro di Kabupaten Barru.

\section{Pengujian Secara Parsial (t-tes)}

Uji t dilakukan untuk menganalisis besarnya pengaruh variabel bebas yaitu Disiplin, Jujur, Kreativitas, Inovatif dan Mandiri secara parsial (sendiri-sendiri) terhadap Produktivitas Pelaku Usaha Rumput Laut Skala Mikro di Kabupaten Barru dengan taraf signifikan yang boleh ditoleransi sebesar 0,05.

Apabila nilai t-hitung lebih besar dari nilai t-tabel dan nilai probabilitas lebih kecil dari taraf signifikan yang telah ditentukan dengan $\alpha=0,05$ maka terdapat pengaruh yang signifikan dari variabel bebas terhadap variabel terikat. Untuk lebih jelasnya hasil analisis uji t dapat dilihat pada tabel berikut.

Tabel 2. Nilai Ikhtisar Hasil Uji t

\begin{tabular}{cccccc}
\hline Variabel & $\begin{array}{c}\text { Koefisien } \\
\text { Regresi }\end{array}$ & t-hitung & t-tabel & $\begin{array}{c}\text { t-signifikan } \\
\text { (Probabilitas) }\end{array}$ & Keterangan \\
\hline Disiplin & 7.949 & 3,938 & 1,671 & 0,001 & Signifikan \\
Jujur & 0.456 & 2,473 & 1,671 & 0,038 & Signifikan \\
Kreativitas & 0.269 & 2,863 & 1,671 & 0,044 & Signifikan \\
Inovatif & 0.213 & 2,964 & 1,671 & 0,010 & Signifikan \\
Mandiri & 0.426 & 2,629 & 1,671 & 0,023 & Signifikan \\
\hline
\end{tabular}

Sumber : Data Primer Diolah

Berdasarkan hasil ikhtisar perhitungan uji-t secara parsial atau sendiri-sendiri di atas, maka dapat diinterpretasikan sebagai berikut:

\section{Disiplin}

Berdasarkan hasil perhitungan untuk variabel disiplin dengan nilai t-hitung sebesar 3,938 lebih besar dari nilai t-tabel sebesar 1,671 dengan probabilitas t-signifikan sebesar 0,001 lebih kecil dari taraf signifikan $\alpha=0,05$, maka variabel disiplin berpengaruh signifikan terhadap Produktivitas Pelaku Usaha Rumput Laut Skala Mikro di Kabupaten Barru.

Arah hubungan yang positif menandakan bahwa semakin tinggi disiplin pelaku usaha dalam bekeja, maka semakin tinggi produktivitas Pelaku Usaha Rumput Laut, artinya semakin meningkatnya efisiensi. Hal ini dibuktikan dengan tingginya tingkat disiplin dan kesungguhan responden dalam mengelola usahanya meskipun secara intelektual pelaku usaha memiliki tingkat pendidikan yang rendah. Di samping itu prilaku kedisiplinan ditunjukkan dengan adanya kepedulian yang baik terhadap jenis pekerjaan yang dipilihnya meskipun sebahagian besar responden melakukan usaha budidaya rumput laut sebagai mata pencaharian sampingan. Kedisiplinan dapat menyebabkan segala sesuatu dapat berjalan secara efektif dan efisien yang mengarah pada peningkatan produktivitas. Sejalan dengan hal tersebut, Romansyah (2012) mengemukakan bahwa kedisiplinan wirausaha dalam menjalankan usaha dapat ditunjukkan melalui konsistensi tindakan yang diperlukan dalam upaya meningkatkan nilai dan pencapaian tujuan usaha yang dijalankan.

\section{Jujur}

Berdasarkan hasil perhitungan untuk variabel jujur dengan nilai t-hitung sebesar 2,473 lebih besar dari nilai t-tabel sebesar 1,671 dengan probabilitas t-signifikan sebesar 0,038 lebih kecil dari taraf signifikan $\alpha=0,05$, maka variabel jujur berpengaruh signifikan terhadap produktivitas pelaku usaha rumput laut skala mikro di Kabupaten Barru. Arah hubungan yang 
positif menandakan bahwa semakin tinggi nilai kejujuran yang ditanamkan oleh pelaku usaha dalam bekerja, maka semakin tinggi Produktivitas hasil yang diperoleh Pelaku Usaha Rumput Laut.

Tingkat kejujuran yang dimiliki oleh pelaku usaha rumput laut di Kabupaten Barru berpengaruh positif terhadap peningkatan produktivitas, meskipun tingkat pemahaman tentang kejujuran dari setiap responden mempunyai perbedaan, responden memberikan informasi mengenai segala sesuatu yang berhubungan dengan aktivitas dalam pengelolaan budidaya rumput laut sesuai dengan kenyataan yang sebenarnya. Setyaningrum (2008), mengemukakan bahwa wirausahawan yang memiliki nilai-nilai kepribadian kewirausahaan memberi nilai tinggi pada ambisi, pencapaian / prestasi, reliabilitas, tanggungjawab, kerja keras, dan kompetensi, optimisme, inovasi, agresivitas, kejujuran, kreativitas, pengakuan sosial, dan pertumbuhan. Hal ini sejalan dengan pendapat Yuwono (2010) menyatakan bahwa karakter individu yang jujur yaitu memiliki tabiat yang bersifat objektif sesuai dengan kebenaran yang diketahuinya dan tabiat yang menunjukkan prinsip dan integritas sehingga bisa dipercaya banyak orang.

\section{Kreativitas}

Berdasarkan hasil perhitungan untuk variabel kreativitas dengan nilai t-hitung sebesar 2,863 lebih besar dari nilai t-tabel sebesar 1,671 dengan probabilitas t-signifikan sebesar 0,044 lebih kecil dari taraf signifikan $\alpha=0,05$, maka variabel kreativitas berpengaruh signifikan terhadap Produktivitas Pelaku Usaha Rumput Laut Skala Mikro di Kabupaten Barru. Arah hubungan yang positif menandakan bahwa semakin tinggi Kreativitas pelaku usaha dalam bekeja, maka semakin tinggi Produktivitas Pelaku Usaha Rumput Laut di Kabupaten Barru.

Setiap manusia dikaruniai daya kreativitas yang berbeda baik yang terbentuk secara alamiah maupun terbentuk karena proses sesuai dengan jenis usaha yang dilakukan termasuk dalam pengelolaan budidaya rumput laut. Kreativitas diperlukan agar dalam berwirausaha terus mengalami perkembangan. Sejalan dengan hal tersebut Romansyah (2012) mengemukakan bahwa tingkat kreativitas dan inovasi tidak hanya didasari pada kemampuan dalam menghasilkan barang/jasa yang berbeda dari sebelumnya tapi juga didasarkan pada tingkat intensitas dalam mengembangkan ide-ide baru sehingga terjadi perubahan secara terus menerus terhadap produk/jasa melalui peluang yang ada.

\section{Inovatif}

Berdasarkan hasil perhitungan untuk variabel Inovatif dengan nilai t-hitung sebesar 2,964 lebih besar dari nilai t-tabel sebesar 1,671 dengan probabilitas t-signifikan sebesar 0,001 lebih kecil dari taraf signifikan $\alpha=0,05$, maka variabel Inovatif berpengaruh signifikan terhadap Produktivitas Pelaku Usaha Rumput Laut Skala Mikro di Kabupaten Barru. Arah hubungan yang positif menandakan bahwa semakin tinggi Inovatif dalam arti membawa perubahan ke arah yang positif, memiliki ide-ide cemerlang, mengubah sumber daya tidak produktif menjadi produktif sehingga memberikan nilai ekonomis, maka semakin tinggi Produktivitas Pelaku Usaha Rumput Laut Skala Mikro di Kabupaten Barru. Adapun bentuk inovasi yang telah dilakukan oleh responden dalam budidaya rumput laut adalah dengan menambahkan botol-botol sebagai pemberat disetiap 1,5-2 meter tali bentangan. Hal ini dilakukan apabila cuaca sangat terik maka botol tersebut diisi setengahnya dengan air . Adapun tujuan dari pengisian botol-botol tersebut adalah sebagai pemberat agar rumput laut tidak mengalami kekeringan dan dapat berkembang dengan baik. Sejalan dengan teori yang dikemukakan oleh Rogers (1995) inovasi adalah seberapa lama seseorang/kelompok/sistem sosial lebih dahulu dalam mengadopsi ide-ide, gagasan, objek/benda baru.

\section{Mandiri}

Berdasarkan hasil perhitungan untuk variabel Mandiri dengan nilai t-hitung sebesar 2,629 lebih besar dari nilai t-tabel sebesar 1,671 dengan probabilitas t-signifikan sebesar 0,023 lebih kecil dari taraf signifikan $\alpha=0,05$, maka variabel Mandiri berpengaruh signifikan terhadap Produktivitas Pelaku Usaha Rumput Laut. Arah hubungan yang positif menandakan 
bahwa semakin tinggi Kemandirian dalam usaha mengelola usaha rumput laut, kematangan emosional dalam mengambil tindakan pada setiap keputusan, risiko tidak perlu dihindari tetapi dikelola dengan manajemen risiko, maka akan berimplikasi pada semakin tingginya Produktivitas Pelaku Usaha Rumput Laut Skala Mikro di Kabupaten Barru.

Baum et al. (2001) mengatakan bahwa sifat seseorang (yang bisa diukur dari ketegaran dalam menghadapi masalah, sikap proaktif dan kegemaran dalam bekerja), memiliki kompetensi umum, kompetensi khusus serta motivasi, berpengaruh secara positif terhadap pertumbuhan usaha. Sejalan dengan hal tersebut Kartono (1985) mengemukakan bahwa kemandirian seseorang terlihat pada waktu menghadapi masalah. Jika masalah itu dapat diselesaikan sendiri tanpa berusaha untuk melibatkan pihak lain dan bertanggung jawab akan segala keputusan yang telah diambil melalui berbagai pertimbangan maka menunjukkan bahwa orang tersebut mampu untuk mandiri. Selanjutnya Antonius (2002) mandiri berarti mampu bertindak sesuai dengan keadaan tanpa meminta atau bergantung pada orang lain dalam bentuk tindakan nyata guna menghasilkan barang/jasa demi pemenuhan kebutuhan hidupnya dan sesama. Selanjutnya Antonious (2002) menjelaskan ciri-ciri orang mandiri:1) mampu bekerja sendiri, 2) menguasai keahlian sesuai dengan pekerjaannya, 3) menghargai waktu dan tanggungjawab. Kemandirian pelaku usaha mikro rumput laut di kabupaten Barru berpengaruh positif, hal ini dibuktikan dengan kemandirian responden untuk tetap menjalankan dan mengembangkan usaha budidaya rumput sesuai dengan pengetahuan dan keterampilan yang telah mereka dapatkan baik sebagai mata pencaharian pokok maupun sampingan meskipun pada saat itu tidak mendapatkan bantuan modal dari dinas Perikanan dan Kelautan Barru.

\section{KESIMPULAN}

Penelitian ini menemukan bahwa variabel disiplin, jujur, kreativitas, inovasi dan mandiri berpengaruh signifikan terhadap produktivitas pelaku usaha rumput laut skala mikro di Kabupaten Barru. Hasil ini diuraikan bahwa kedisiplinan responden ditunjukkkan dengan kesungguhan responden dalam mengelola usahanya serta adanya kepedulian yang baik terhadap jenis pekerjaan yang dipilihnya. Selanjutnya perilaku jujur ditunjukkan dengan adanya niat baik dari responden memberikan informasi mengenai segala sesuatu yang berhubungan dengan aktivitas dalam pengelolaan budidaya rumput laut sesuai dengan kenyataan yang sebenarnya.Kreativitas responden ditunjukkan dengan keinginan untuk mau menerima perubahan secara positif diantaranya mengikuti pelatihan-pelatihan untuk menambah khasanah wawasan berpikir. Inovasi responden ditunjukkan dengan pemanfaatan tehnologi sederhana yang menunjang dalam budidaya rumput laut. Kemandirian responden ditunjukkan untuk tetap menjalankan dan mengembangkan usaha budidaya rumput meskipun tidak selalu mendapatkan bantuan dari Dinas Kelautan dan Perikanan Kabupaten Barru. Dari lima variabel bebas yang diajukan, ternyata variabel disiplin menunjukkan pengaruh yang paling signifikan diantara variabel lain terhadap produktivitas pelaku usaha rumput laut skala mikro di Kabupaten Barru.

Adapun saran dalam penelitian ini. Pertama, penerapan Nilai kewirausahaan perlu diterapkan oleh pelaku usaha mikro dalam menjalankan usaha budidaya rumput laut karena berpengaruh positif terhadap produktivitas. Kedua, dinas Perikanan dan Kelautan Kabupaten Barru dalam memberikan penyuluhan dan pelatihan yang berhubungan dengan pembudidayaan rumput laut sebaiknya menambahkan materi betapa pentingnya penerapan Nilai kewirausahaan bagi setiap pelaku usaha mikro budidaya rumput laut

\section{DAFTAR PUSTAKA}

Armstrong, Michael. (2003), How to be An Even Better Manager, Edt :Lyndon Saputra, Penerbit Binarupa Aksara, Batam

Jong. J.P.J. De \& Kemp, R. (2003). Determinants of Coworkers's Innovative behaviour: An Investigation into Knowledge Intensive Service. International Journal of Innovation Management.

Mardiatmo. (2004). Kewirausahaan: Surakarta: Yudishtira. 
Nasution, S. (1972). Didaktik Sekolah Pendidikan Guru, Asas-asas Didaktik Metodologi Pengajaran dan Evaluasi. Depdikbud

Prijodarminto, Soegeng. (1994). Disiplin Kiat Menuju Sukses. Bandung: Paramita

Suryana. (2008). Kewirausahaan: Pedoman Praktis, Kiat dan Proses Menuju Sukses. Edisi Revisi. Penerbit Salemba Empat. Jakarta.

Sumahamijaya. (2001). Membina Sikap Mental Wiraswasta. Jakarta: Gunung Jati (Mandiri)

Sahabuddin, R. (2012).Pengaruh Motivasi Berprestasi dan Efikasi Diri Terhadap Komitmen Berwirausaha serta Dampaknya Pada Kinerja usaha. Disertasi Fakultas Ekonomi. Universitas Padjadjaran. Bandung

Setyaningrum. (2008). Tesis Hubungan antara Nilai-Nilai Pribadi Pemilik/Manajer Dengan Strategi Bisinis Dalam Meningkatkan Kinerja.UNDIP

Yuwono, Budi. (2010). SQ. Reformation. Jakarta: Gramedia

Rogers. Everett. M. (1995). Diffussion of Innovations. New York: The Free Press.

Baum, J. Robert, Edwin A. Locke dan Ken G. Smith. (2001). A Multidimensional Model Of Venture Growth. Academic Management Journal. 44 (2), 292-303.

Kartono, K. (1985). Psikologi Sosial Perusahaan dan Industri. Jakarta: CV. Rajawali

Antonius, G. (2002). Relasi Dengan Diri Sendiri.Jakarta.P.T.Gramedia. 